\title{
A LETTER TO THE UNDERWORLD A RESEARCH REPORT ON THE CURSE TABLET AQ-2 ${ }^{1}$
}

\begin{abstract}
Summary: This paper presents the second one of the two newly discovered curse tablets from Aquincum, Pannonia. It gives a reading for both of its sides after considering the letter-types, onomastical features, invoked deities, magical formulas, technical mistakes and vulgar Latin characteristics of the text. These traits show the tablet was worded in close connection with the other one, but they were not written by the same hand.
\end{abstract}

Key words: curse tablet, Aquincum, Dis Pater, Aeracura, Mercurius, epistula

In 2015 two new curse tablets were found in Aquincum, Pannonia, originally coming from an area of cremation graves dated to the $2^{\text {nd }}$ and $3^{\text {rd }}$ centuries in the Eastern cemetery of the civil town. Previously, I published a preliminary report on one of them (Aq-3 as a working title). ${ }^{2}$ This paper is discussing the main results of a pre-examination of the other one, namely Aq-2 (inv. nr. 2000.11.2973a).

${ }^{1}$ I would like to express my thanks to the Director of BTM Aquincum Museum, dr Paula Zsidi, leader of the excavation at issue and to dr Gábor Lassányi, the archaeologist responsible for the complex examination for assigning the curse tablet to me. I am also grateful to dr Béla Adamik (HAS Momentum - ELTE University) who helped me a lot both with useful suggestions and comments on my work. The present paper has been prepared within the framework of the project OTKA (Hungarian Scientific Research Fund) No. K 108399 entitled "Computerized Historical Linguistic Database of Latin Inscriptions of the Imperial Age" (see: http://lldb.elte.hu/) and of the project entitled "Lendület ('Momentum') Research Group for Computational Latin Dialectology" (Research Institute for Linguistics of the HAS), and was presented at the First International Workshop on Computational Latin Dialectology, Budapest, 7th April 2016.

${ }^{2}$ BARTA, A.: Ito Pater, Eracura and the Messenger. A Preliminary Report on a New Curse Tablet from Aquincum. ACD 51 (2015) 101-113. For archaeological aspects, see that paper p. 101. For abbreviations of corpora, see http://lldb.elte.hu/admin/abbrev_bibl.php. 


\section{EXTERNAL FEATURES}

The Aq-2 is also a nearly rectangular lead tablet, its maximum size is $8.1 \mathrm{~cm} \times 9.3 \mathrm{~cm}$. The wavy edge (Fig. 2) could be the product of a fast and strained cutting. The textfield was prearranged by a vertical line or a margin on the left side. It was folded six times starting at the bottom of the text and resulting finally in seven units (Fig. 1). The first, innermost and smallest one was broken off when the tablet was unfolded but it is still readable.

In contrast with Aq-1 ${ }^{3}$ and Aq-3, Aq-2 was written in full on both sides. The text is well preserved, only the uppermost line on the outer side is damaged, thus almost nothing but traces of letters can be seen there - further study may reveal them. The inner side is more arranged (Fig. 3): the scribe kept a margin on the left side, but the letters became denser on the right side. The text did not fill in all the blank spaces, some one or two lines remained unwritten at the bottom of the tablet. The outer side seems to be less ordered (Fig. 4). Firstly, the margins are not as strict here as they are on the inner side. Secondly, as there was not enough room for the text planned in advance (Fig. 5) the scribe turned it 90 degrees "counterclockwise", and went on writing that way (Fig. 6). In horizontal orientation only two and a half lines were written. As a consequence of the re-use and the damaged condition of the outer side, further investigation is still required to rebuild the entire text.

In comparison to Aq-3, the letter-forms barely differ, but it is not likely that they were made by the same hands. The main difference is the simple form of letter A which is very characteristic in Aq-3, and that those specific Greek letter-elements are missing in Aq-2. Moreover, the letter S of Aq-3 looks as if it is standing on a base line while in Aq-2 it has an extra line above. Letter D became more rectangular, it is not drop-like anymore.

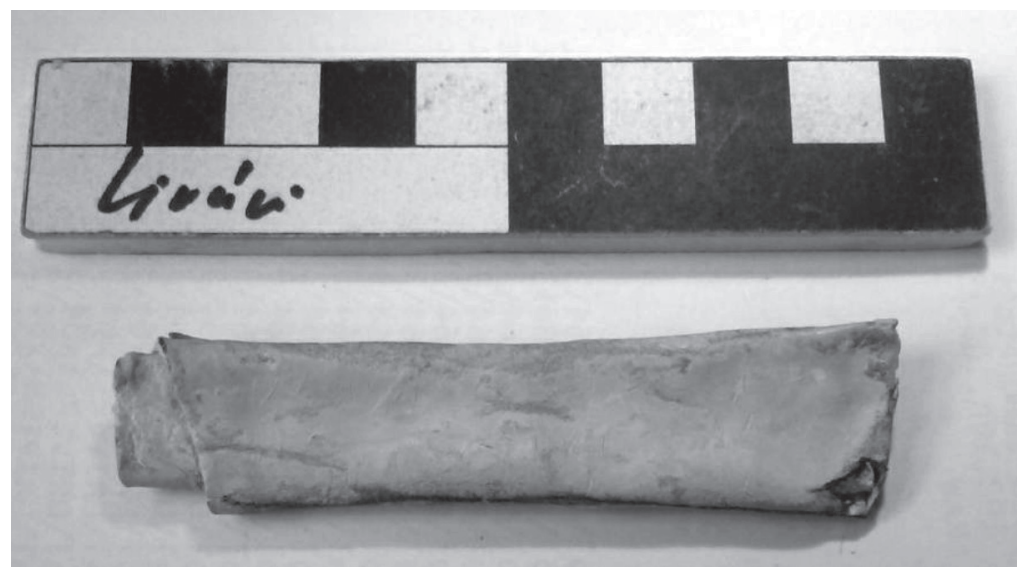

Fig. 1. Aq-2 before unfolding (photo by G. Lassányi)

\footnotetext{
${ }^{3}$ Aq-1=TitAq III 1436. Recently: BARTA, A. - LASSÁNYI, G.: Az elgörbült nyelv. Új adatok egy aquincumi átoktábla rítusához. [Tongue twisted. New data to the ritual of a curse tablet from Aquincum. In Hungarian]. Ókor 2015/1, 70-74.
} 


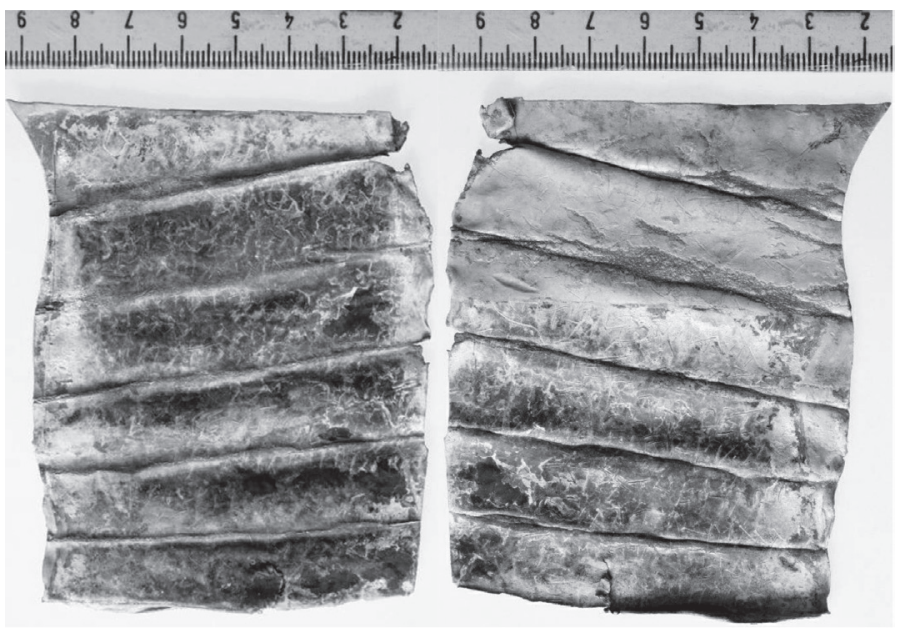

Fig. 2. Inner side (left) and outer side (right) of Aq-2 (photo by G. Lassányi)

\section{THE INNER SIDE}

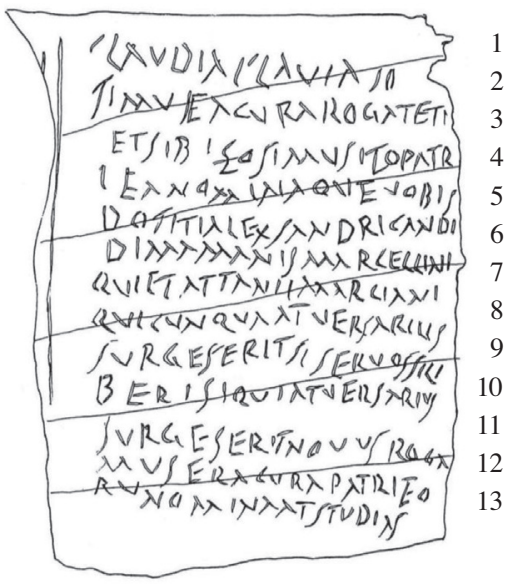
CLAVDIAFLAVIA SO
SIMVSEACVRAROGATETP
TETSIBIZOSIMVSITOPATR
I EANOMINAQVEVOBIS
DOTITIALEXSANDRICANDI
DIMAMANISMARCELLINI
QVIETATTANIIMARCIANI
QVICVNQVAATVERSARIVS
SVRGESERITSI SERVOSSILI
BER I SIQVIATVERSARIVS
SVRGESERITNOVVSROGA
MVS ERACVRAPATRIEO
RVNOMINAATSTVDIAS

Fig. 3. Inner side of Aq-2 (drawing by A. Barta)

\section{II.1. Persons involved in cursing}

The inner side starts with three names, they must be the customers of the magician. These names are common in Aquincum: the female ones (Claudia, Flavia) were in use almost in every period, but Zosimus is known only from the $2^{\text {nd }}$ century. ${ }^{4}$ This latter name, of Greek origin, is written in a less common form regarding the starting $\mathrm{S}$ in

${ }^{4}$ TitA $q$ I 271, TitA $q$ II 585 and a military diploma: CIL XVI 123 (TitAq = KovÁCS, P. - SZABÓ, Á.: Tituli Aquincenses I-III. Budapest 2009-2011). 
line 1 , but it is repeated in the third line, this time spelt correctly (or in a more standard form), with a $\mathrm{Z}^{5}$

Names (mostly cognomina ${ }^{6}$ ) in lines 5-7 refer to the people cursed in this tablet. All of them are genitive in a possessive construction subordinated to the word nomina which refers to the name list to be handed to the infernal deities. ${ }^{7}$ Most of the names are well known and correctly written. There is only one spelling mistake: in Alexander, the $\mathrm{X}$ is followed by a redundant $\mathrm{S} .{ }^{8}$ Attanius is a less common form of a name which occurs mainly as Atanius or Athanius, ${ }^{9}$ this version has only one instance on a funerary inscription from Lambaesis (CIL VIII 3042). Attanius could derive either from the ancient Italic praenomen Attus, ${ }^{10}$ or a vernacular name Atto/Atta common in Pannonia and in Aquincum, too. ${ }^{11}$ Moreover, it could originate even from geographical names. ${ }^{12}$

The nominative form to Mamanis cannot be established incontestably. Three similar names are known from inscriptions, but they have given rise to much controversy. The nearest instance is from Aquincum, mentioning a mother: Val(eriae) MAMANI matri kar(issimae) (TitAq II 737). ${ }^{13}$ Similarly, a woman is named on CIL VI 34002 from Rome: Gatta Marcanus et Arista MAMANA donarunt monumentum

${ }^{5}$ On the outer side the name was written in a third form, IOSIMVS which could be a simple technical mistake of the scribe. Or, it can attest palatalization, cf. HERMAN, J.: Vulgar Latin. Pennsylvania 2000, 42-45: see examples for the inverse version: ZENVARIA pro Ianuaria ICVR II 4498; ADZAB pro Adiabenici CIMRM I 407 (CIMRM = VERMASEREN, M. J.: Corpus Inscriptionum et Monumentorum Religionis Mithriacae. 2 vols. Den Haag 1956-1960). For this kind of consonant changes in Pannonian inscriptions, see ADAMIK, B.: Remarks on the Changes of Consonantism in Pannonian Latinity as Evidenced by the Inscriptions. In WRIGHT, R. (ed.): Latin vulgaire - latin tardif VIII. Actes du VIIIe colloque international sur le latin vulgaire et tardif, Oxford, 6-9 septembre 2006. Hildesheim 2008, 103-111.

${ }^{6}$ Titus as cognomen cf. TitAq II 571 (Marcus Aurelius Titus).

${ }^{7}$ For the function and semantic field of nomen in curse tablets, see URBANOVÁ, D. - FrANEK, J.: Il campo semantico di "nomen" nelle tavole defixionum. In Latin Vulgaire - Latin Tardif XI. Proceedings of the 11th International Conference on Late and Vulgar Latin, 1-5 September 2014, Oviedo. In print.

${ }^{8}$ It is a common feature usually reflecting the scribe's hesitation in a compound sound, or in later times his counterbalance to the weakening of this cluster. HERMAN (n. 5) 47-48.

${ }^{9}$ Italia, Roma, Lusitania, Dalmatia, male and female version also: Atani- AE 1972, 121; AE 1982, 95; CIL I 1792; CIL II 6251; CIL III 2191; CIL VI 12571; CIL VIII 26076; CIL X 1589; CILCaceres 2 , 688; AE 1987, 301; AE 1994, 843; AE 1994, 843-844; SdOstia 3 p. 152 and Athani- CIL VI 12572; CIL IX 338. (CILCaceres =ESTEBAN ORTEGA, J.: Corpus de inscripciones latinas de Cáceres.2. Turgalium. Cáceres 2012. SdOstia $3=$ FLORIANI SQuARCIASPINO, M.: Scavi di Ostia. Le Necropoli 1. Le tombe di età repubblicana e Augustea. Roma 1955).

${ }^{10}$ ThLL I 1169. A certain Atanius Secundus, contemporary to emperor Gaius, is mentioned by

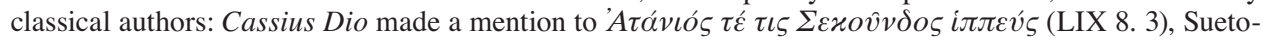
nius did not name him, but knew his story (Gaius 27. 2).

${ }^{11}$ For Atta: P(ublius) Ael(ius) Atta (TitAq I 261), Aur(elius) Att(a?) (TitAq I 131), Atta Bataionis f(ilius) ann(orum) LV negotiator (RIU 156 [RIU = Die römischen Inschriften Ungarns. Budapest 1972-]); Attae Nivionis f(ilio) Azalo (CIL III 1985). For Atto: ... Martinus at Atto lib(erti) et hered(es) (AE 1986, 573).

${ }^{12}$ Pliny mentions a settlement in Persia (NH VI 149: Homnae et Attanae, quae nunc oppida maxime celebrari a Persico mari nostri negotiatores dicunt - "and also Homna and Attana, towns said by our traders to be now the most frequented ports in the Persian Gulf" transl. H. Rackham), and there was a certain Attanum in Aquitania, at least in the late Antiquity (today Saint-Yrieix-la-Perche, http://imperium. ahlfeldt.se/places/13480).

${ }^{13}$ EDH HD054749 gives the nominative form to MAMANI as Mamana, with a question mark at the end. (EDH=Epigraphic Database Heidelberg. http://edh-www.adw.uni-heidelberg.de/home) 
lucandum ..., her name was interpreted as a spelling mistake of Mamma by ILS 7934, or ,vermutlich Weiterbildung des Kinderwortes Mamma" by Th. Mommsen. ${ }^{14}$ In CIL X 2965 D(is) M(anibus) / Sittiae Euthy/ciae libertae / et MAMANI / Sitti Ianuari patro/ni b(ene) m(erenti) f(ecit) the liberta Sittia Eutychia is traditionally referred as the mother (MAMANI also - allegedly misspelled) of Sittius Ianuarius patronus. As regards these two latter instances, the Thesaurus Linguae Latinae suggests also that they could be the alternations of mamma. ${ }^{15}$ At the same time, the two unquestionable readings from Aquincum (dative Mamani, genitive Mamanis) may attest the existence of a 3rd declension name but its nominative form is still uncertain. On the one hand, it can be either Maman (according to the paradigm of Paean, gen. Paeanis), or a parisyllabic Mamanes/Mamanis (like Epiphanes or Hypanis, -is $m$ ). On the other hand, having preference for interpreting it as a female form on the base of the other instances, the paradigm of Mama, gen. Mamanis seems to be plausible parallel to the well attested paradigms of Nice, gen. Nicenis; Tyche, gen. Tychenis. ${ }^{16}$

Similarly to the other two curse tablets from Aquincum, Aq-2 is also of a judicial character which bears witness to a discord between two groups of men and women, together. The words adversarius and SVRGESERIT set the tablet in a litigious milieu. ${ }^{17}$ The text does not reveal anything about the named persons. Zosimus, Alexander and the name with genitive Mamanis can refer to Oriental people, but the rest are common Latin names. Their legal status is also open to question, seemingly none of them is $d u o$ or tria nomina, and they cannot be bound to any other known person from Aquincum. The expression si servus si liber ${ }^{18}$ is the only element which may refer to the fact that both freemen and slaves were involved, just as in Aq-1 where people with duo nomina and the word coservi were mentioned among the opposing parties. ${ }^{19}$ This expression has occurred only in prayers for justice from Britannia so far, when directing the curse against unknown culprits in thievery. Aq-2 was not written among circumstances of this kind. What they have in common is the words quicumque and even more si quis adversarius novus which refer to someone yet unknown who may appear in this trial as an adversary. The difference between the two very similar expressions quicumque adversarius surrexerit ${ }^{20}$ and si qui adversarius surrexerit (divided by si servus si liber)

${ }^{14}$ Mommsen, Th.: Gatta und Arista. In Helbig, W. (ed.): Strena Helbigiana sexagenario obtulerunt amici. Leipzig 1900, 198-199. There is one more interpretation of Mamana (of CIL VI 34002) proposed previously by scholars: parallel to Marcanus, they both are thought to had been built from Marcius and Mammius atypically.

${ }^{15}$ ThLL VIII 246.

${ }^{16}$ Cf. CIL VI 14897 ... Antonia Stratonice fecit sibi et ... Noniae Stratoniceni filiae suae carissimae; CIL XII 5072 Dis Manibus Pomponiae Phileni quae vixit ...

${ }^{17}$ BARTA (n. 2) 106, n. 21. (ThLL I 843-844 gives the meaning of adversarius as $\left.\alpha \dot{v} \tau i \delta \iota x o \varsigma\right)$.

${ }^{18}$ Formally, the $\mathrm{O}$ in SERVOS is an orthographical tradition concerning the words ending in -VVS. However, the final I of LIBERI must be a technical mistake, maybe a mistakenly copied mark from the draft, because there is a little more distance from the rest of the letters.

${ }^{19} \mathrm{Cf}$. Aq-1: according to Roman naming traditions, Gaius Mutilius and Iulia Nissa are likely freemen, while among the cursed people a coservos can be read (line 3) referring to 'fellow slaves'.

${ }^{20}$ QVICVNQVA with a misspelled $e$ at the end, maybe under the influence of pronouns with $-a$ - in the last syllable quidam, quisnam, quispiam and quisquam; for the hypercorrection of ATVERSARIVS see BARTA (n. 2) 107, n. 25; for SVRGESERIT see BARTA (n. 2) 106, n. 22. 
can be that the first one refers to all those persons who are already involved in the case, while the second one is directed against those who may join the group of adversaries in the future - this would be similar to Aq-3 where those who may write a counter-curse are cursed in advance. The si servus si liber can belong to both of the two adversarii. As it can be observed in parallels, the expression is rather attached to the first one. ${ }^{21}$ But as regards the yet unknown persons, it should be rather taken to the second one.

\section{II.2. Summoned deities}

The same deities are invoked in Aq-2 as in Aq-3. On the inner side, Aeracura and Dis Pater are mentioned twice: in line 2, EACVRA with a missing $\mathrm{R}$ due to technical mistake, while in the bottom ERACVRA correctly; in lines 3-4 ITOPATR/I is the same version as in Aq-3 with a missing D, consequently, for reasons unknown, ${ }^{22}$ and at the bottom simply PATRI with the missing first element. The third god, Mercurius is mentioned on the outer side.

Syntactically, these god names are taken by verbs (line 2: rogat, lines 11-12: rogamus). The end of line 2 and the beginning of line 3 is the only part of the tablet where the visible letters or letter fragments do not make out a meaningful word (ETI/IET). As regards parallels and common spelling mistakes, et petit is the most plausible conjecture. ${ }^{23}$

Normatively, rogo is construed with an accusative or double accusative, so does peto, but as for peto in certain cases the accusative of the asked person can be substituted by the preposition $a b$ with ablative. Both verbs can take a consecutive clause, either with a conjunction $u t$ or $n e$, or asyndetically. In this text, the god name $\mathrm{E}<\mathrm{R}>\mathrm{ACVRA}$ is a nominative or ablative form, or with a missing word-ending $-m$ it can be an accusative as well. At the same time, ITOPATRI and PATRI are clearly dative forms, or supposing an $i-e$ alternation, they can be ablatives, too. For the resolution of this inconsistency we have to mind the followings. According to curse tablets, in some rare cases rogo

${ }^{21} d f x$ 3.2/10 ... qui caracallam meam involaverit, si vir si femina, si servus si liber, uti eum dea Sulis maximo leto adigat. dfx 3.2/24 ... qui mihi fraudem fecit, si vir si femina si servus si liber, nisi se retegens istas species adtemplum tuum detulerit ( $d f x=\mathrm{K}$ ROPP, A.: Defixiones. Ein aktuelles Corpus lateinischer Fluchtafeln. Speyer 2008).

${ }^{22}$ For the version ITOPATER see BARTA (n. 2) 108-109 - additionally to the alleged compound Ditopater: usually the word Dis refers to Dis Pater, the ruler of the underworld, but there are some instances where the underworld itself is meant by Dis, cf. hostes ab imo conditi Dite exeunt (Sen. Tro. 432 "Their buried enemies are emerging from deepest Dis" transl. John G. Fitch), umbrae / non tacitas Erebi sedes Ditisque profundi / pallida regna petunt (Lucan. 1. 454-456 Dis is set parallel to the abstract Erebus).

${ }^{23}$ Both classical authors and inscriptions attest that rogo and peto were used together as a phrase: ... id sibi ut donaret rogare vel vehementissime petere coepit ... (Cic. Verr. 4. 66); ... a vobis optimi municipes peto et rogo per salutem sacratissimi principis Antonini Augusti Pii ... (middle of $2^{\text {nd }} \mathrm{c}$.; AE 1894, 00148); ... rogo et peto omnem clerum ... (CIL 05, 02305); ... bene merenti fecit et petit et rogat uti loc(us) ei reservetur (ILCV 04879 [ILCV = DIEHL, E.: Inscriptiones Latinae Christianae Veteres. Berlin 1925-1967]); in curse tablets: ... rogo et peto magnam virtutem vestram ... (AE 2008, 223); ... vos precatur et petit rogat vos numina ... (AE 2007, 260) 
could take a dative. ${ }^{24}$ If we consider only the first sentence, the interpretation would be obvious: the first verb takes Aeracura in an accusative form (actually with a not marked word-ending $-m$ ). ITOPATRI is subordinated to peto, which instead of a prepositional construction is a simple dative or ablative case. ${ }^{25}$ However, the text ending sentence ruins this easy-to-follow explanation, because the scribe seems to use the two god names in the same case subordinated only to one verb (rogamus). Relying upon these findings, if peto was not only dropped out mistakenly, it seems the two verbs rogo and peto take the same case. Because of their similar meaning the case which they require became the same. The scribe's specific but consequent use of oblique cases attest general uncertainty of the declension system.

And as regards the second part of these two sentences, both rogo and peto require mostly an accusative or a subordinated clause in the meaning of 'to ask sg' or 'to ask sy to do sg'. In the first sentence it is missing, but the second one ends in ATSTVDIAS. It is likely to be the subjunctive form of the verb studeo but has never been attested with the prefix ad- (*adstudeo). ${ }^{26}$ In order to make emendation as little as possible, the conjunction at would be reasonable as it can commence an imprecation or a wish, and sometimes a command, a request or an entreaty. ${ }^{27}$ But in consideration of parallels, in this place a conjunction $u t$ is expected most (which connects the subordinated studeas to the main clause rogamus). Though AT was written with complete certainty, due to the similarity of these two letters A and V, it could have been misspelled easily.

Normatively, studeo requires a dative. In this text, nomina, the names of the customers' adversaries are what the gods should concentrate on. It is an accusative form subordinated to rogamus and is not repeated nor referred to by a pronoun for the second time, thus this last sentence is elliptical. ${ }^{28}$

The first sentence is elliptical, too. This last, stressed studeas can be understood here, also subordinated to rogat et petit. Lacking that, the sentence would be hardly understandable. The point under discussion is not whether the customers (Claudia, Flavia and Zosimus) ask the gods (Aeracura and Dis Pater) for the list of adversaries,

${ }^{24}$ DIONISIA DENATIAI ANCILLA ROGAT DEIBVS ... $(d f x$ 2.2.3/1); TIBI ROGO METVNVS $\ldots(d f x 3.14 / 3)$ and an inscription from a Britannia, $8^{\text {th }}$ c.: ... ROGO OMNIBVS AMMVLANTIBVS IBI EXORENT (CIIC 1, 427 [CIIC = MACALISTER, R. A. S. (ed.): Corpus Inscriptionum Insularum Celticarum. Vol. 1-2. Dublin 1945-1949).

${ }^{25}$ HERMAN (n. 5) 57.

${ }^{26}$ With $e$ - $i$ alternation or conjugation change (studio studĕre pro studeo studēre), and at- pro adjust like in ATVERSARIVS, see above.

${ }^{27}$ At te Iuppiter et dique omnes perdant (P1. Ps. 836-837); at di deaeque dentibus tuis escam negent (Priap. 78. 1).

${ }^{28}$ If we consider $d f x$ 1.4.4/8-1.4.4/12 (Bona pulchra Proserpina, Plutonis uxor, sive me Salviam dicere oportet. Eripias salutem, corpus, colorem, vires, virtutes Ploti, tradas Plutoni viro tuo ...), a rather different interpretation could arise, which still needs further investigation. According to these paralells, in Aq-2 Aeracura could also be asked to recommend the adversaries to his consort, Dis Pater: ... rogamus Aeracuram: Patri eorum nomina at studeas. In this case, the subject of studeas would be only Aeracura which is more convenient with this singuar verb form, and not both Aeracura and Dis Pater. 'We ask Aeracura, well, make Dis Pater deal with their names (i.e. with them)' or 'We ask Aeracura: recommend their names (i.e. them) to Dis Pater'. (I am grateful to Daniela Urbanová who called my attention to $d f x$ 1.4.4/8-12.) 
but the customers ask the gods to concentrate on the list of enemies, so that these latter ones can get binding or punishment from the powers of the underworld. ${ }^{29}$ as follows:

To sum up what has been discussed above, the text of the inner side of Aq-2 runs

1 Claudia, Flavia, ${ }^{\ulcorner} \mathrm{Z}=\mathrm{S}{ }^{\urcorner} \mathrm{o}-$

2 simus $<\mathrm{A}>$ eracura $<\mathrm{m}>$ rogat et $\mathrm{p}$. [e]-

3 tr $\left.^{\top} \mathrm{i}=\mathrm{E}\right\urcorner \mathrm{t}$ (?) sibi Zosimus $<\mathrm{a}><\mathrm{D}>\mathrm{it}^{\top} \mathrm{e}=\mathrm{o}^{\urcorner}$Patr-

$4{ }^{\mathrm{r}} \mathrm{e}=\mathrm{I}^{\mathrm{r}}$ ea nomina, $\mathrm{qu}<\mathrm{a}>\mathrm{e}$ vobis

5 do: Titi, Alex\{s\}andri, Candi-

6 di, Mamanis, Marcellini

7 qui et Attanii, Marciani,

8 quicunqu ${ }^{r} \mathrm{e}=\mathrm{A}^{\urcorner} \mathrm{a}^{\mathrm{r}} \mathrm{d}=\mathrm{T}^{\urcorner}$versarius

9 sur'rex=GES`erit, si serv'u $=\mathrm{O}^{\top}$ s, si li-

10 ber $\{\mathrm{i}\}$, si qui $\mathrm{a}^{\mathrm{d}} \mathrm{d}=\mathrm{T}^{\urcorner}$versarius

11 sur'rex=GES'erit novus, roga-

12 mus $<\mathrm{A}>$ eracura $<\mathrm{m}>$, Patr ${ }^{\mathrm{e} e m}=\mathrm{I}^{\top}$ eo-

$13 \mathrm{ru}<\mathrm{m}>$ nomina at (=ut?) $\mathrm{stud}^{\top} \mathrm{e}=\mathrm{I}^{\urcorner}$as.

The text arranged in a classical standard version, without diacritical marks:

Claudia, Flavia, Zosimus Aeracuram rogat et petit sibi Zosimus a Dite Patre ea nomina, quae vobis do, Titi, Alexandri, Candidi, Mamanis, Marcellini qui et Attanii, Marciani, quicumque adversarius surrexerit, si servus, si liber, si qui adversarius surrexerit novus, rogamus Aeracuram, Patrem eorum nomina: at (ut?) studeas.

Claudia, Flavia, Zosimus ask Aeracura, and Zosimus as for himself requests Dis Pater <to concentrate on> those names which I am handing over to you: of Titus, Alexander, Candidus, Mama(?), Marcellinus known as Attanius as well, Marcianus, whoever will act like an opponent, whether slave or free, if someone new will act like an opponent, we ask Aeracura and Dis Pater: do concentrate on their names, (too).

${ }^{29}$ Similarly, on other curse tablets mando, defero, mitto, do, lego, and recipio are used to express the same conception: Nomina data, delata, legata ad inferos, ut illos per vim corripiant, dfx 5.1.4/7; Haec nomina hominum et equorum, quae dedi vobis, cadant, dfx 11.2.1/10; Dis inferis, vos rogo ut recipiatis nomen Luxiae, dfx 2.2.2/1; Helenus eius nomen inferis mandat, $d f x$ 1.4.4/1; nomen delatum, $d f x$ 1.5.3/1. 


\section{THE OUTER SIDE}

As mentioned above, the text on the outer side requires further investigation. Although there are only three lacunas at this moment, their essential positions detain us from the complete, coherent interpretation of the text. Neither of the disposable text-fragments

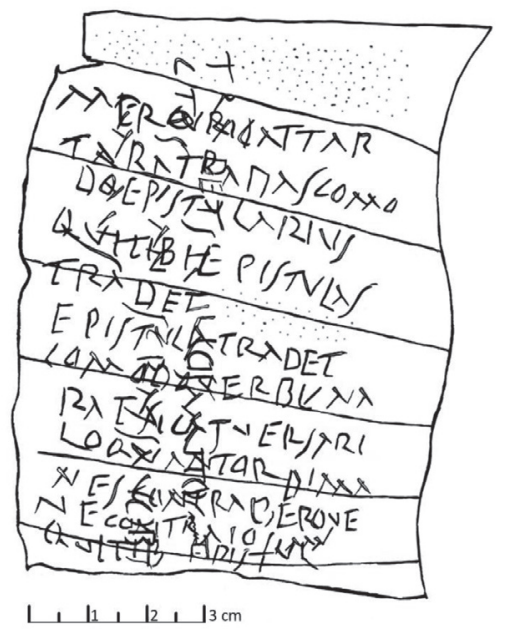

Fig. 4. The outer side of Aq-2 (drawing by A. Barta)

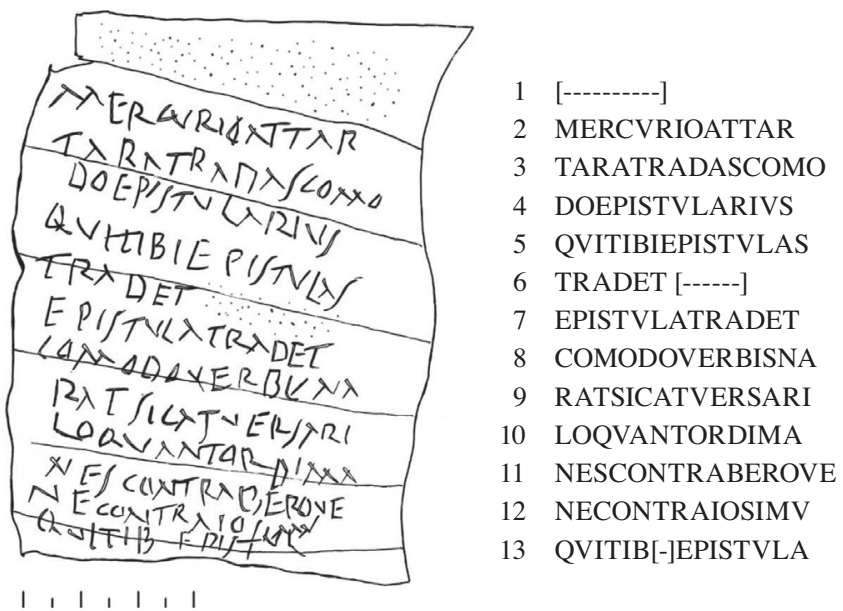

Fig. 5. Vertical lines on the outer side of Aq-2 (drawing by A. Barta)

are sufficient to find an undoubted connection between the two sides of the tablet. However, there are two possible reasons for the connection: on the one hand, the unity of the three gods of Aq-3 (Dis Pater, Aeracura and Mercurius) is named on different sides of Aq-2 (inner side: Aeracura, Dis Pater, outer side: Mercurius) which can prove 
that the two sides belong together. Moreover, Muta Tacita of Aq-3 recurs as well in the expression illos mutos [ta]/citos of the outer side of Aq-2 that sets finally all the gods of Aq-3 on both sides of Aq-2. On the other hand, in line 12 IOSIMV is mentioned who may be the same person as ZOSIMVS and SOSIMVS of the inner side, written differently again. ${ }^{30}$

Below, the discernible elements are going to be presented.

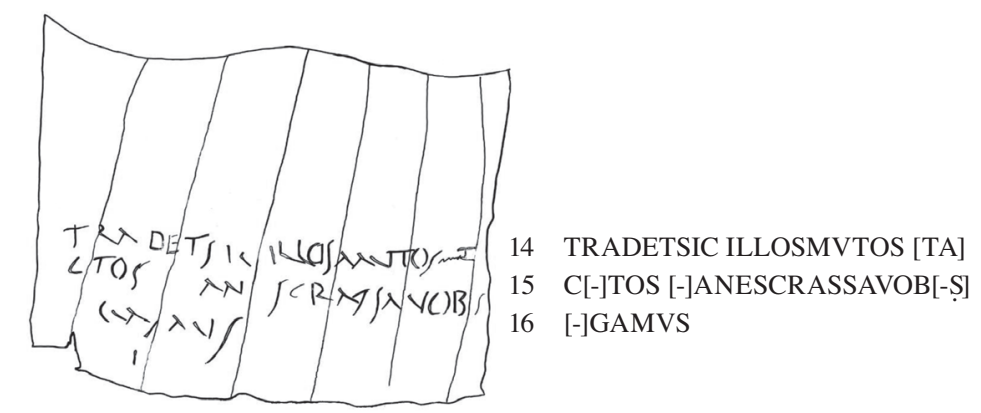

Fig. 6. Vertical and horizontal lines on the outer side of Aq-2 (drawing by A. Barta)

After the first yet unreadable line Mercury is mentioned with a dative or ablative ending. He is followed by the name of Tartarus, agreeing to the preposition $a d .^{31}$ Both Mercury and Tartarus occur in Aq-3, close to each other. Without the first line it is problematic to decide whether the actor of tradas is Mercurius or someone else, because trado could take a dative, or a construction of $a d$, too. ${ }^{32}$ The two possible solutions can be: it is Mercury who is asked to hand over to the underworld those who will hand letters (curses) to him, or someone unknown (maybe a nekydaimon or a spirit of the deceased person of this grave) is asked to hand over to Mercury in the underworld those who will hand letters (curses) to him. As regards parallels the latter seems less probable. The main reason is that in Latin curses the buried people are usually mentioned just as analogies for the requested punishment, ${ }^{33}$ contrasted to papyri, their spirits are rarely forced (or attested to be forced) to do something in favour of the cursing persons. Moreover, epistularius is much more conceivable with Mercury the messenger, though it has never been attested before. The word itself with this ending -arius usually thought to be the occasional variant of the more common, established form

\footnotetext{
30 See n. 5.

${ }^{31} \mathrm{Ad}$ written as AT, just like in ATVERSARIVS again.

${ }^{32}$ Similar construction with the same words: Furtim igitur dant Mercurio mandata ad Iovem / adflictis ut succurrat (Phaedr. I 2).

${ }^{33}$ A well known example: Quomodo mortuus, qui istic sepultus est, nec loqui ne sermonari potest, sic Rhodine apud Marcum Licinium Faustum mortua sit... (dfx 1.4.4/3)
} 
of epistularis, both of late imperial date. ${ }^{34}$ Concerning the archaeological dating, this instance would be the first occurrence of epistularius, similarly to Tricerberi of Aq-3. ${ }^{35}$

In lines 8-9 letters are formed firmly, and at first sight they seem to be VERBVM/RAT. However, the slight deviations in the letter-forms suggest another reading: verbis na $<r>$ rat. ${ }^{36}$ Verbum narrat could occur only in negative expressions, ${ }^{37}$ the plural verba would be a better match, but according to the letter-forms verbis is the most conceivable form. Thus, verbis narrat could mean: 'he/she speaks by words'. According to the pair of conjunctions quomodo-sic, ${ }^{38}$ this section is a similia similibus. Quomodo verbis narrat, sic atversarii loquantur, ${ }^{39}$ 'as he/she does speak, so may our opponents speak'. The lacunas make difficult to guess to whom it refers. The most plausible solution can be the epistularius. Since this tablet is a tongue-binding curse which usually was produced to make the opponents mute, verbis narrat must refer to a mute person, to a mute messenger. This person could be the deceased ${ }^{40}$ who had been designated to hand this curse to the powers of the underworld.

Di manes are inserted similarly to Aq-3 before naming the enchanter (or enchanters) which is marked by the preposition contra. Beroe is the easiest, most known solution for this name BEROVENE, with an intrusive V. This form may be the same word building as occurred previously in the case of Mamanis, namely, on the model of Tyche, gen. Tychenis it would be from Beroe, gen. Beroenis an accusative Beroenem, agreed to contra, written as Bero\{v\}ene $<m>$. At the same time, less possibly NE in the beginning of line 11 can be a negative particle too, ne contra ' $Z=I^{\top}$ osimu $<m>$ 'not against Zosimus'. ${ }^{41}$

The lowermost sentence is not interrupted but is going on after the scribe has turned the tablet 90 degrees "counterclockwise". That is the third repetition of qui tibi epistulas tradet. The only doubtless part of the horizontal text stands in its first line:42 sic illos mutos [ta]/c[i]tos. The last two words seem to be vob[is / ro]gamus, with conjecture. If it is correct, then there is another evidence of rogo subordinating a dative as it was mentioned above.

${ }^{34}$ AdAmS, J. N.: Social Variation and the Latin Language. Cambridge 2013, 543.

${ }^{35}$ Cf. ThLL. For Tricerberi, see BARTA (n. 2) 109-110.

${ }^{36}$ I am grateful to Dr. Sara Chiarini (Otto-von-Guericke-Universität Magdeburg) for her useful comments on this section.

${ }^{37}$ Cic. Clu. 185: de eo quod quaerebatur verbum nullum fecit?

${ }^{38}$ COMODO pro quomodo attesting the weakening of the semiconsonantal [w] after [k], like in line 3, cf. HERMAN (n. 5) 48. The confusion between QV - C is attested in Aq-3, too (CVI pro qui, CVOMODO pro quomodo).

${ }^{39}$ ATVERSARI pro adversarii with a simple I and the recurring mistake of AT- pro ad-.

${ }^{40}$ Ancient authors refer to the underworld as the place of silence, cf. Ov. F. V 609. and in curses we find similar expressions: Quomodo mortuus qui istic sepultus est nec loqui nec sermonari potest sic Rhodine apud Marcum Licinium Faustum mortua sit nec lowui nec sermonari possit. (dfx 1.4.4/3)

${ }^{41}$ Zosimus is an enchanter of the inner side. If these two persons are the same, there cannot be any reason why it is not him against whom the adversaries should speak weakened.

${ }^{42}$ I am grateful to Daniela Urbanová who also drew my attention to the word cras in curse tablets (as regards the senseless CRASSA in line 15): cf. $d f x$ 11.1./20 in crastino die; $d f x$ 11.2.1/31 ne currere possint cras; TermeDiocleziano-01, p. 629 rogamus cras deas vestras et Christum nostrum. 
To sum up what has been discussed above, the text of the outer side of Aq-2 runs as follows:

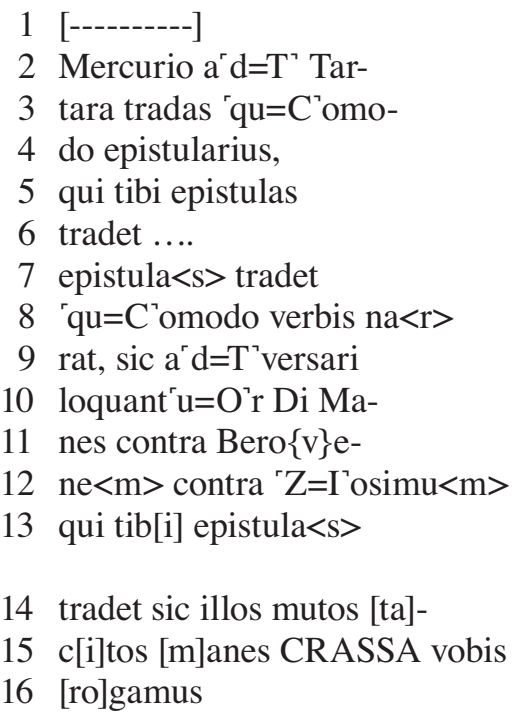

The interpretable text arranged in a classical standard version, without diacritical marks:

... Mercurio. Ad Tartara tradas quomodo epistularius, qui tibi epistulas tradet ... epistulas tradet quomodo verbis narrat, sic adversarii loquantur di manes contra Beroen, contra Zosimum, qui tibi epistulas tradet, sic illos mutos tacitos manes ... vobis rogamus

... to Mercurius. As a messenger, hand over to Tartarus those who will hand letters to you ... will hand letters ... just as he/she does speak, so may our opponents speak, oh infernal souls, against Beroe and against Zosimus, who will hand letters to you, so the infernal souls may ... them mute and silence, we ask you.

\footnotetext{
Andrea Barta

Lendület ('Momentum') Research Group for Computational Latin Dialectology

Research Institute for Linguistics of the Hungarian Academy of Sciences

H-1068 Budapest, Benczúr u. 33.

Hungary

barta.andrea@nytud.mta.hu
} 